\title{
Facts about Serpentine Rock and Soil Containing Asbestos in California
}

JULIE FRAZELL, Program Representative, and RACHEL ELKINS, Pomology Farm Advisor, University of California Cooperative Extension, Lake County; ANTHONY TOBY O'GEEN, Associate Soil Resources Specialist in Cooperative Extension, Department of Land, Air and Water Resources, University of California, Davis; ROBERT REYNOLDS, Director Emeritus, Lake County Air Quality Management District; JAMES MEYERS, Occupational and Environmental Health Specialist Emeritus, Department of Biological and Agricultural Engineering, University of California, Davis

\section{What is Serpentine?}

The term "serpentine" refers to a group of minerals that make up serpentinite rock. "Serpentine" and "serpentinite," however, are often used interchangeably. Serpentinite is a metamorphic rock formed when water and rock are exposed to low temperatures (about 400 to $600^{\circ} \mathrm{C}$ ) and metamorphic processes (high pressures) within the earth's crust. Serpentinite is a type of ultramafic rock, consisting predominantly of magnesium silicate and iron oxide minerals.

Most ultramafic rocks, including serpentinite, contain naturally occurring asbestos (NOA) particles (fig. 1), microscopic needlelike particles of asbestos or asbestos-like fibers. The term "NOA" also refers to a group of relatively common fibrous minerals in rock (U.S. Geological Survey 2007). NOA minerals include chrysotile and fibrous forms of five amphiboles. These forms include a complex group of widely distributed magnesium-iron silicates (rock-forming minerals), crocidolite, amosite, anthophyllite, actinolite, and tremolite. The most common NOA particle in ultramafic rocks is chrysotile.

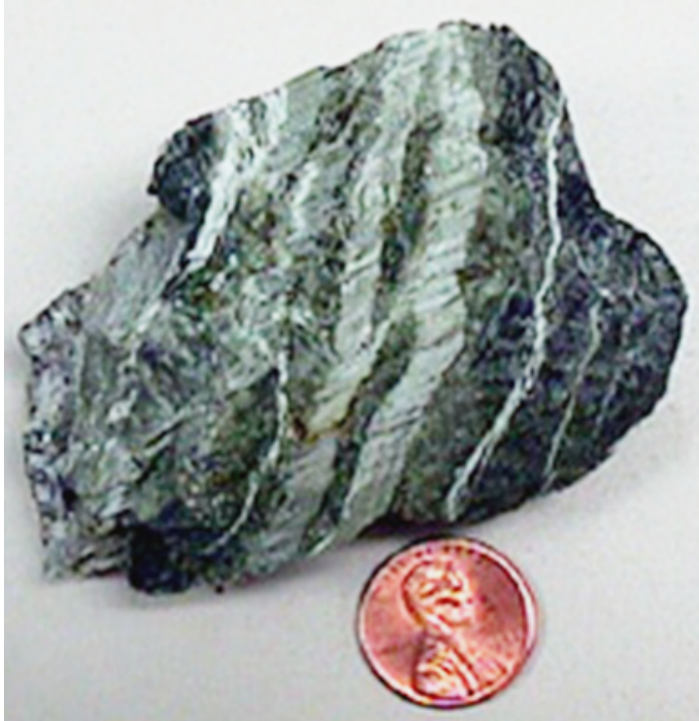

NOA particles are a known human health risk. Asbestos has been classified as a carcinogen by state, federal, and international agencies. If serpentinite or ultramafic rock is located on your property or was used to construct your driveway or walkways, there is a risk of asbestos exposure where you live.

\section{How to ReCognize Serpentine LANDSCAPES}

Serpentine is California's state rock. The state contains over $1,988$ square miles ( 3,200 sq. $\mathrm{km})$ of serpentinite outcrops, and it is present in 42 of the 58 counties. It has a distinctive greenish-gray to bluish-black color and may have a waxy

Figure 1. Serpentine rock with veins of NOA. Source: U.S. EPA Naturally Occurring Asbestos Web site, http://www.epa.gov/asbestos/pubs/clean.html. 
- any form of mechanical exposure or disturbance of serpentinite bedrock

\section{IMPROVEMENT OF EXISTING CONTROL MeAsures}

On July 20, 2000, the California Air Resources Board (ARB) strengthened its asbestos airborne toxic control measures by eliminating the use of asbestos-containing serpentine rock for surfacing operations, such as road covering or landscaping. Dr. Alan Lloyd, ARB chairman, stated, "This amendment improves the existing control measure and better protects the public from the cancercausing effects of asbestos-laden dust from gravel roads, parking lots and landscaping" (California Air Resources Board 2000).

\section{Living WITH Serpentine SoILS}

Soils that form from serpentinite are an important natural resource in California. They support a wide range of unique and rare plant and animal life. Taking simple, common-sense precautions helps reduce the risk to residents who have serpentine soils or rock on their property. Serpentine soils or rock should be left undisturbed and stabilized to reduce exposing or releasing fibers into the environment. As long as fibers remain bound in rock or soil, they pose very little health threat.

\section{How Can You as a Homeowner REDUCE Your Exposure to Asbestos DUST?}

Avoid the following outdoor activities when serpentine soil is dry and dusty:

- rototilling, digging, jackhammering, grading, or plowing

- using leaf blowers

- driving on unpaved roads or driveways

- riding horses or moving livestock

- construction or renovation activities that disturb the soil, such as pool installation

To control dust around your home, always

- presoak dry ground thoroughly before disturbing the soil

- use water to clean sidewalks and driveways

- avoid using (pave them over, if necessary) unpaved walkways, driveways, or roadways that may have asbestos-containing rock or soil
Landscaping can reduce exposure of asbestos fibers:

- To reduce natural erosion and dust, cover serpentine soil with a layer of organic mulch or asbestos-free soil 3 to 6 inches $(7.5$ to $15 \mathrm{~cm}$ ) thick. Plant gardens and yards with serpentinetolerant plants (see ANR Publication 8400, Trees and Shrubs for Northern California Serpentine Landscapes, http://anrcatalog.ucdavis.edu/ pdf/8400.pdf).

- Provide adequate water until plants are well established.

- Keep heavily-trafficked areas moist.

Prevent fibers from entering the home:

- Asbestos fibers can be tracked into the home on shoes. Remove and clean shoes before entering the house.

- Fibers can settle on clothing. Wash exposed clothing separately from nonexposed clothing.

- Asbestos fibers can be transferred to family members by pets. Keeping pets in yards with grass or shrubs planted over bare soil can lower contact with soil and reduce tracking into the home. Where this is not possible, wash pets with running water from a hose following contact with bare soils.

If asbestos fibers may have been brought into the home:

- Avoid

- dry-cloth dusting or feather dusting

- sweeping or vacuuming

- Replace with

- damp-cloth dusting or wet mopping

- washable area rugs

- HEPA filter vacuum.

\section{ACKNOWLEDGMENTS}

The information for this publication was compiled as part of the Naturally Occurring Asbestos in Serpentine Soils Education Program, a joint project of the Lake County Air Quality Management District and the University of California Cooperative Extension, Lake County. The authors gratefully acknowledge the California Air Resources Board, California Geological Survey, and the University of California McLaughlin Reserve for providing important background information. Thanks also to Carolyn Shaffer for assisting with publication revision and formatting. 


\section{REFERENCES}

California Air Resources Board. 2000. ARB strengthens asbestos air toxic control measure. News release. ARB Web site, http://www.arb.ca.gov/newsrel/nr072000. htm. 2008. Naturally occurring asbestos. ARB Web site, http://www.arb.ca.gov/toxics/ asbestos/asbestos.htm, December 9, 2008. . Staff report: Initial statement of reasons for proposed rulemaking; public hearing to consider the adoption of a regulatory amendment identifying asbestos as a toxic air contaminant. California Office of Health Hazard Assessment Web site, http://oehha.ca.gov/air/toxic_contaminants/ html/Asbestos.htm, August 6, 2009.

California Geological Survey. Geological survey: Asbestos. California Department of Conservation Web site, http://www. conservation.ca.gov/CGS/minerals/ hazardous_minerals/asbestos/Pages/Index. aspx, December 9, 2008.

Frazell, J., R. Elkins, A. O'Geen, R. Reynolds, and N. Gentry. 2009. Trees and shrubs for Northern California serpentine landscapes. Oakland: University of California Agriculture and Natural Resources Publication 8400. ANR Communication Services Web site, http:// anrcatalog.ucdavis.edu/pdf/8400.pdf.

Lake County [California] Air Quality Management District Web site, http://lcaqmd.net/, December 9, 2008.

National Toxicology Program. 2005. Asbestos. In Report on carcinogens. 11th ed. U.S. Washington, DC: U.S. Department of Health and Human Services, Public Health Service, National Toxicology Program.

Netstate.com. Web site, http://www.netstate.com/ states/symb/rocks/ca_rock.htm.

Pan, X., H. W. Day, W. Wang, La. A. Beckett, and M. B. Schenker. 2005. Residential proximity to naturally occurring asbestos and mesothelioma risk in California. American Journal of Respiratory and Critical Care Medicine 172:1019-1025.
University of California Cooperative Extension. Asbestos Serpentine Soils Education Program. UCCE Lake County Web site, http://celake.ucdavis.edu/Master_Gardener/ Serpentine_Demonstration_Garden.htm, December 10, 2008.

University of California McLaughlin Reserve. McLaughlin Reserve protects California's state rock. University of California Integrated Hardwood Range Management Program Web site, http://danr.ucop.edu/ ihrmp/oak102.htm, December 8, 9, and 10, 2008.

U.S. Environmental Protective Agency. Fact sheet \#1: Health information on asbestos. ARB Web site, http://www.arb.ca.gov/toxics/ asbestos/1health.pdf, December 9, 2008. Fact sheet \#2: School advisory for naturallyoccurring asbestos. ARB Web site, http:// www.arb.ca.gov/toxics/asbestos/2school.pdf, December 9, 2008.

. Fact sheet \#3: Ways to control naturallyoccurring asbestos dust. ARB Web site, http://www.arb.ca.gov/toxics/ asbestos/3control.pdf, December 9, 2008. - Fact sheet \#4: Naturally occurring asbestos around your home. ARB Web site, http:// www.arb.ca.gov/toxics/asbestos/4home.pdf, December 9, 2008.

- General information fact sheet: Naturallyoccurring asbestos. ARB Web site, http:// www.arb.ca.gov/toxics/asbestos/general.htm, December 9, 2008.

- Naturally occurring asbestos (NOA) Web site, http://www.epa.gov/asbestos/pubs/ clean.html.

U.S. Geological Survey. 2008. Asbestiform minerals and human health. USGS Human Health Web site, http://health.usgs.gov/inhalation/ asbestiform.html, August 28, 2009. 


\section{FOR FURTHER INFORMATION}

To order or obtain ANR publications and other products, visit the ANR Communication Services online catalog at http://anrcatalog.ucdavis.edu or phone 1-800-994-8849. You can also place orders by mail or FAX, or request a printed catalog of our products from

\author{
University of California \\ Agriculture and Natural Resources \\ Communication Services \\ 6701 San Pablo Avenue, 2nd Floor \\ Oakland, California 94608-1239 \\ Telephone 1-800-994-8849 \\ (510) $642-2431$ \\ FAX (510) 643-5470 \\ E-mail: danrcs@ucdavis.edu \\ (ㄷ)2009 The Regents of the University of California \\ Agriculture and Natural Resources
}

All rights reserved.

No part of this publication may be reproduced, stored in a retrieval system, or transmitted, in any form or by any means, electronic, mechanical, photocopying, recording, or otherwise, without the written permission of the publisher and the authors.

\section{Publication 8399}

\section{ISBN-13: 978-1-60107-675-5}

The University of California prohibits discrimination or harassment of any person on the basis of race, color, national origin, religion, sex, gender identity, pregnancy (including childbirth, and medical conditions related to pregnancy or childbirth), physical or mental disability, medical condition (cancer-related or genetic characteristics), ancestry, marital status, age, sexual orientation, citizenship, or service in the uniformed services (as defined by the Uniformed Services Employment and Reemployment Rights Act of 1994: service in the uniformed services includes membership, application for membership, performance of service, application for service, or obligation for service in the uniformed services) in any of its programs or activities.
University policy also prohibits reprisal or retaliation against any person in any of its programs or activities for making a complaint of discrimination or sexual harassment or for using or participating in the investigation or resolution process of any such complaint.

University policy is intended to be consistent with the provisions of applicable State and Federal laws.

Inquiries regarding the University's nondiscrimination policies may be directed to the Affirmative Action/Equal Opportunity Director, University of California, Agriculture and Natural Resources, 1111 Franklin Street, $6^{\text {th }}$ Floor, Oakland, CA 94607, (510) 987-0096. For information about ordering this publication, telephone 1-800-994-8849. For assistance in downloading this publication, telephone 530-754-3927.

An electronic copy of this publication can be found at the ANR Communication Services catalog Web site, http://anrcatalog.ucdavis.edu.

UC. This publication has been anonymously peer PEER reviewed for technical accuracy by University of California scientists and other qualified professionals.

This review process was managed by the ANR Associate Editor for Natural Resources.

web-09/09-SB/CR 